\title{
IMPLEMENTASI KOMUNIKASI PERUSAHAAN PADA BUMD KOTA BANDUNG (Studi Deskriptif Kuantitatif Mengenai Acara Siaran Dialog Interaktif PDAM Kota Bandung di Radio Swasta Lokal Bandung)
}

\author{
Aat Ruchiat Nugraha \\ Dosen Program Studi Hubungan Masyarakat Fakultas Ilmu Komunikasi - Universitas Padjadjaran \\ E-mail: arn@unpad.ac.id/aat.prodihumas@hotmail.com
}

\begin{abstract}
ABSTRAK. Komunikasi perusahaan PDAM Kota Bandung masih dapat dikategorikan belum optimal, dimana berbagai informasi yang menyangkut permasalahan perusahaan dengan publiknya (internal dan eksternal) begitu "berserakan", khususnya tentang pelayanan secara kualitas, kuantitas dan kontinuitas suplai air bersih. Penelitian ini mengenai aspek kegiatan komunikasi yang dilakukan oleh Direksi PDAM Kota Bandung di radio swasta lokal dalam upaya meningkatkan pemahaman pelanggan terhadap perusahaan. Desain penelitian ini menggunakan explanatory survey dengan teknik pengumpulan data melalui penyebaran angket kepada sejumlah responden yang terpilih secara acak sederhana. Hasil penelitian ini menunjukkan bahwa komunikasi perusahaan PDAM Kota Bandung dalam bentuk Dialog Interaktif di radio swasta lokal dapat meningkatkan pengetahuan, pemahaman, dan perilaku positif dari pelanggan terhadap perusahaan. Kesimpulan penelitian ini menunjukkan bahwa Dialog Interaktif merupakan kegiatan komunikasi perusahaan yang cukup efektif dalam menyelesaikan permasalahan yang berkaitan dengan proses layanan perusahaan bagi pelanggannya.
\end{abstract}

Kata Kunci: Komunikasi Perusahaan, Pelayanan dan sikap pelanggan

\section{IMPLEMENTATION OF CORPORATE COMMUNICATIONS At BANDUNG CITY GOVERMENT COMPANY (Quantitative Descriptive Study of PDAM Bandung City Interactive Dialogue on Private Radio Local at Bandung)}

\begin{abstract}
Communications company PDAM Bandung still be considered not optimal, where a variety of information concerning the company's problems with public (internal and external) so "scattered", especially on the service in the quality, quantity and continuity of supply of clean water. This research on aspects of communication activities undertaken by the Board of Directors PDAM Bandung in local private radio stations in an effort to increase understanding of the company's customers. The design of this study using explanatory survey data collection techniques by distributing questionnaires to a randomly selected respondents is simple. The results of this study indicate that the communications company PDAM Bandung in the form of an interactive dialogue on local private radio stations to increase knowledge, understanding, and positive behaviors of customers towards the company. The conclusion of this study indicate that the interactive dialogue is a corporate communications activities are quite effective in solving the problems related to the company's services to its customers.
\end{abstract}

Key words: Corporate Communications, Service and Customer Attitudes

\section{PENDAHULUAN}

Keberadaan Perusahaan Daerah Air Minum (PDAM) sebagai unit pelayanan umum milik Pemerintah Kota/Kabupaten sangat vital dalam memenuhi kebutuhan air bersih bagi masyarakat perkotaan dan sekitarnya. Walaupun terdapat sumber air bersih lainnya, namun secara keseluruhan yang paling dominan digunakan oleh masyarakat perkotaan adalah bersumber dari suplai PDAM. Seiring dengan perjalanan waktu dan pertumbuhan penduduk perkotaan yang terus meningkat, maka kebutuhan pelayanan akan air bersih khususnya yang diolah PDAM semakin bertambah pula. Pada saat yang sama sering kali pelayanan air bersih PDAM dari waktu ke waktu menunjukkan trend yang menurun dari segi kuantitas dan kontinuitas. Hal ini akhirnya memicu lahirnya 'protes' dari pengguna/pelanggan air PDAM.

Sebagai bentuk 'protes' dari pelanggan terhadap PDAM antara lain masalah pelayanan, pembayaran tarif rekening air, penunggakan rekening air, keluhan gangguan meter, debit air yang berkurang, ketidakteraturan jadwal pergiliran sementara aliran air, jadwal penghentian air yang tidak menentu, dan lain sebagainya. Berbagai bentuk 'protes' dari pelanggan ini menjadi tantangan dan peluang bagi manajemen PDAM untuk memberikan peningkatan pelayanan air bersih kepada masyarakat secara optimal. Adapun, salah satu upaya manajemen PDAM berkomunikasi dengan publiknya untuk menangani berbagai 'protes' dari pelanggannya tersebut yaitu dengan melaksanakan aktivitas kehumasan yang memanfaatkan teknologi media massa khususnya, radio siaran guna meningkatkan citra dan sikap positif dari pelanggannya melalui kegiatan "Dialog Interaktif" di radio-radio swasta lokal. Kegiatan ini merupakan bagian dari Ekternal Relations yang dibangun khususnya dengan Customer Relations PDAM Kota Bandung dalam usaha menjembatani hubungan jarak antara perusahaan dengan pelanggannya agar lebih intens dan familiar dimata khalayak. Beberapa sikap pelanggan sebelum adanya acara "Dialog Interaktif" PDAM Kota Bandung di radio 
swasta lokal yaitu penyampaian pengaduan tentang pelayanan PDAM yang harus disampaikan ke Kantor Pusat PDAM, dan perhatian pelanggan yang masih cenderung lebih mengutamakan pembayaran rekening listrik dan telepon dibandingkan rekening PDAM. Dari kondisi ini dapat dilihat bahwa perhatian pelanggan terhadap eksistensi PDAM masih rendah dan kurang loyalitas terhadap perusahaan.

Kegiatankomunikasiperusahaanmelalui “Dialog Interaktif” PDAM Kota Bandung di radio-radio swasta lokal ini dilaksanakan secara rutin setiap tiga bulan sekali. Kadang-kadang intensitas acara dialog interaktif dapat dilakukan secara insidental berdasarkan atas permintaan pihak Manajemen Radio maupun Direksi PDAM Kota Bandung untuk meng'clear'kan berbagai permasalahan yang menyangkut PDAM yang telah diterima ke meja redaksi radio maupun meja Direksi PDAM Kota Bandung. Dengan terlaksananya kegiatan komunikasi perusahaan ini, manajemen perusahaan mengharapkan adanya peningkatan sikap dari pelanggannya mengenai pemberian informasi tentang kebocoran aliran air dan penyampaian keluhan, saran dan kritik terhadap pelayanan maupun kinerja PDAM. Informasi apa saja yang disampaikan pelanggan dalam kegiatan komunikasi perusahaan ini, tentunya dapat menghasilkan keuntungan diantara kedua belah pihak, seperti pihak perusahaan menjadi mengetahui jaringan pelayanan air bersih yang sering mengalami kebocoran, pembayaran rekening air menjadi lancar dan bagi pelanggan tentunya ada kepastian peningkatan pelayanan air bersih secara kualitas, kuantitas dan kontinuitas yang didapatkan. Berdasarkan latar belakang yang telah diuraikan, maka penulis merumuskan masalah, "Bagaimana Implementasi Kegiatan Komunikasi Perusahaan BUMD Pemerintah Kota Bandung di Radio Swasta Lokal dapat Meningkatkan Sikap Positif Pelanggan Terhadap Perusahaan?"

\section{METODE}

Metode yang dipakai dalam penelitian ini adalah metode survai deskriptif. Menurut Singarimbun dalam buku Metode Penelitian Survai, penelitian survai yaitu penelitian yang mengambil sampel dari satu populasi dan menggunakan kuesioner atau angket sebagai alat pengumpulan data yang pokok. Pada umumnya yang merupakan unit analisa dalam penelitian survai adalah individu. Lebih jauh lagi disebutkan bahwa penelitian survai dapat digunakan untuk maksud penjajagan (eksploratif), deskriptif, penjelasan (eksplanatori), evaluasi, prediksi, penelitian operasional dan pengembangan indikator-indikator sosial (Singarimbun dan Effendi, 1995:3-4).

Penelitian mengenai implementasi komunikasi perusahaan PDAM Kota Bandung dalam meningkatkan sikappositifpublikterhadapperusahaanmerupakansebuah penelitian survai yang bertujuan untuk menggambarkan (deskriptif), dimana peneliti mengembangkan konsep dan menghimpun fakta, akan tetapi tidak melakukan pengujian hipotesa (Singarimbun dan Effendi, 1995:5). Penelitian deskriptif menurut Isaac dan Michael (dalam Rakhmat, 2002) bertujuan melukiskan secara sistematis fakta atau karakteristik populasi tertentu atau bidang tertentu secara faktual dan cermat (Rakhmat, 2002:22).

\section{HASIL DAN PEMBAHASAN}

Suatu perusahaan akan sukses di mata publik, apabila perusahaan dapat menjalin hubungan yang baik dengan pelanggannya secara simultan dengan mengetahui keadaan objektif publik yang menjadi sasarannya melalui kegiatan komunikasi perusahaan yang terjadwal dengan baik. Salah satu bentuk komunikasi perusahaan yang dilakukan oleh PDAM Kota Bandung yaitu menyelenggarakan kegiatan "Dialog Interaktif" yang disiarkan secara rutin di radio-radio swasta lokal Bandung. Acara dialog interaktif ini berisikan penyampaian informasi mengenai keluhan, saran, kritik dan pertanyaan seputar layanan PDAM yang bersifat timbal balik antara komunikator perusahaan (Direksi dan Ka.Sie. Humas \& Protokol PDAM Kota Bandung) dengan pelanggan dan penyampaian kebijakan baru PDAM Kota Bandung. Adapun respon yang terbentuk dalam acara dialog interaktif yang berlangsung selama 1-2 jam ini mendapat respon cukup baik dari pendengar, terlihat dari banyaknya penelepon dan SMS (Short Message Service) yang masuk dan dibahas dalam acara tersebut.

Secara teknis, acara dimulai tepat pukul 08.00 pagi, dan narasumber menyampaikan materi perbincangan selama 5-10 menit. Kemudian penyiar dan narasumber melakukan tanya jawab seputar materi. Setelah itu, barulah penyiar membuka termin pertanyaan bagi pendengar yang ingin memberikan pertanyaan mengenai materi yang disampaikan melalui telepon maupun Short Message Service (SMS).Materi yang diberikan sangatlah beragam, dari mulai sosialisasi kegiatan, kebijakan, pemasangan jaringan aliran air baru hingga penampungan keluhan. Jika ada keluhan mengenai jaringan atau pelayanan langganan maka petugas PDAM akan langsung turun ke lapangan untuk menanganinya. PDAM merasa perlu melaksanakan kegiatan ini karena PDAM belum memiliki suatu wacana, baik di media cetak maupun media elektronik, yang khusus menyajikan kebijakan-kebijakan, pelayanan dan informasi kegiatan. Maka dengan acara dialog interaktif ini, baik pihak PDAM maupun pelanggan dapat saling berkomunikasi dan berinteraksi secara intens.Secara data kuantitatif hasil penelitian menunjukkan bahwa: 
Tabel 1. Keterkaitan Antara Kredibilitas Sumber dengan Aspek Kognitif Pelanggan

\begin{tabular}{|c|c|c|c|c|c|c|c|c|}
\hline \multirow{3}{*}{$\begin{array}{l}\text { Kredibilitas } \\
\text { Narasumber }\end{array}$} & \multicolumn{6}{|c|}{ Aspek Kognitif } & \multirow{2}{*}{\multicolumn{2}{|c|}{ Jumlah }} \\
\hline & \multicolumn{2}{|c|}{ Tinggi } & \multicolumn{2}{|c|}{ Sedang } & \multicolumn{2}{|c|}{ Rendah } & & \\
\hline & $\mathrm{f}$ & $\%$ & $\mathrm{f}$ & $\%$ & $\mathrm{f}$ & $\%$ & $\mathrm{f}$ & $\%$ \\
\hline Baik & 34 & 56,7 & 8 & 13,3 & 1 & 1,7 & 43 & 71,7 \\
\hline Kurang Baik & 4 & 6,6 & 1 & 1,7 & 1 & 1,7 & 6 & 10,0 \\
\hline Tidak Baik & 1 & 1,7 & 6 & 10 & 4 & 6,6 & 11 & 18,3 \\
\hline Jumlah & 39 & 65,0 & 15 & 25,0 & 6 & 10,0 & 60 & 100,0 \\
\hline
\end{tabular}

Berdasarkan tabel 1. menunjukkan bahwa mayoritas responden yaitu sebanyak 56,7\% memiliki tingkat pengetahuan dan pemahaman materi komunikasi perusahaan dalam bentuk Dialog Interaktif PDAM Kota Bandung yang tinggi berpendapat bahwa kredibilitas narasumber adalah baik dalam arti komponen kredibilitas komunikator telah terpenuhi seperti pengalaman narasumber, jabatan narasumber, penguasaan materi dan derajat keakraban narasumber telah sesuai dengan yang diinginkan oleh audiens. Hal ini menunjukkan bahwa terdapat faktor kredibilitas narasumber sangat berpengaruh terhadap pengetahuan audiens. Menurut Philip Kotler pesan yang disampaikan oleh sumber pesan yang menarik memperoleh perhatian yang lebih besar dan akan diingat. Selain itu sumber pesan haruslah mempunyai kredibilitas yang didasari oleh keahlian, sifat dapat dipercaya dan kesukaan dalam hal ini, sumber kejernihan suara, humor dan sifat alaminya (Kotler,1995:717).

Kemudian, hanya $6,6 \%$ yang memiliki pengetahuan dan pemahaman materi komunikasi perusahaan yang berupa Dialog Interaktif PDAM Kota Bandung yang rendah berpendapat bahwa kredibilitas sumber Dialog Interaktif PDAM tidak baik. Hal ini dapat terjadi karena responden mengganggap bahwa sumber Dialog Interaktif tidak berpengaruh terhadap proses penambahan pengetahuan dan pemahaman pelanggan tentang PDAM sebab pelanggan sebenarnya sudah tahu tentang PDAM yaitu sebagai perusahaan yang melayani masyarakat dalam penyediaan air minum. Namun, disisi lain ada 6,6\% dari responden yang memiliki aspek kognitif tinggi menyatakan bahwa kredibilitas sumber Dialog Interaktif kurang baik karena mereka beranggapan bahwa yang menjadikan pelanggan tahu akan PDAM adalah pelanggan itu sendiri yang aktif bertanya pada bagian informasi PDAM dan membaca informasi di media massa yang berkaitan dengan PDAM Kota Bandung sehingga sedikitnya mereka tahu karakteristik yang selalu menjadi narasumber di acara Dialog Interaktif.

Tabel 2. menunjukkan adanya kecenderungan kredibilitas sumber komunikasi perusahaan yang berupa acara Dialog Interaktif PDAM Kota Bandung memiliki keterkaitan dengan penilaian responden terhadap pengetahuan dan pemahaman materi Dialog Interaktif PDAM Kota Bandung. Terbukti 38,3\% dari responden yang menyatakan kredibilitas sumber adalah baik, sehingga mereka mempunyai perasaan dan penilaian positif terhadap pelayanan PDAM bagi pelanggannya. Hal ini sesuai dengan alasan yang dikemukakan oleh responden yang menyatakan bahwa perasaan suka pada pelayanan PDAM disebabkan oleh narasumber yang mengakomodir permasalahan seputar keluhan pelanggan PDAM dalam Dialog Interaktif yang ditanggapi secara langsung oleh pihak manajemen untuk dapat diselesaikan dengan baik. Selain, tingkat kredibilitas yang mendukung tingginya aspek kognitif pelanggan dalam program Dialog Interaktif PDAM Kota Bandung di radio siaran yaitu adanya sifat keunggulan dalam acara siaran di radio biasanya isi pembicaraanya langsung menyentuh pada aspek pribadi, dengan pendekatan pribadi, sehingga acara di radio biasanya menjadi teman pribadi yang setia dan sekaligus akrab (Romli, 2009:20).

\section{Tabel 2: Keterkaitan Antara Kredibilitas Sumber dengan Aspek Afektif Pelanggan}

\begin{tabular}{|c|c|c|c|c|c|c|c|c|}
\hline \multirow{3}{*}{$\begin{array}{l}\text { Kredibilitas } \\
\text { Narasumber }\end{array}$} & \multicolumn{6}{|c|}{ Aspek Afeksi } & \multirow{2}{*}{\multicolumn{2}{|c|}{ Jumlah }} \\
\hline & \multicolumn{2}{|c|}{ Tinggi } & \multicolumn{2}{|c|}{ Sedang } & \multicolumn{2}{|c|}{ Rendah } & & \\
\hline & $\mathrm{f}$ & $\%$ & $\mathrm{f}$ & $\%$ & $\mathrm{f}$ & $\%$ & $\mathrm{f}$ & $\%$ \\
\hline Baik & 23 & 38,3 & 7 & 11,7 & 13 & 21,7 & 43 & 71,7 \\
\hline Kurang Baik & 4 & 6,7 & 0 & 0 & 2 & 3,3 & 6 & 10,0 \\
\hline Tidak Baik & 5 & 8,3 & 3 & 5,0 & 3 & 5,0 & 11 & 18,3 \\
\hline Jumlah & 32 & 53,3 & 10 & 16,7 & 18 & 30,0 & 60 & 100,0 \\
\hline
\end{tabular}

Sedangkan sebanyak 21,7\% responden menyatakan narasumber Dialog Interaktif PDAM adalah baik namun, memiliki tingkat afeksinya rendah. Hal ini diakibatkan oleh kurangnya loyalitas mereka terhadap PDAM sehingga mereka kurang peduli terhadap permasalahan pelayanan PDAM bagi pelanggannya tetapi, mereka tetap mengikuti acara Dialog Interaktif tersebut dan mereka menyatakan bahwa narasumber dalam Dialog Interaktif PDAM adalah baik, karena yang menjadi narasumber adalah orang yang telah terbiasa menangani permasalahan pelanggan PDAM. Dan 8,3\% responden mempunyai perasaan positif pada pelayanan PDAM karena mereka berpendapat bahwa pihak PDAM telah berusaha menjalin hubungan yang baik dengan pelanggannya sehingga permasalahan seputar keluhan pelanggan dapat terselesaikan secara cepat dengan tanpa memperhatikan kredibilitas narasumber Dialog Interaktif PDAM Kota Bandung yang akibatnya menilai narasumber menjadi tidak baik.

Selanjutnya, agar menjadi media yang ekonomis untuk menyebarkan informasi yang cepat dan langsung kepada publik internal dan eksternal, komunikasi lisan (dialog interaktif), sebagai proses komunikasi dua arah, memungkinkan informasi diterima. Sudah tentu, dampak komunikasi tersebut sebagian besar bergantung pada kepribadian si pembicara dan daya penyampaian pesannya (Moore, 2004 : 237). 
Tabel 3. Keterkaitan Antara Kredibilitas Sumber dengan Aspek Konatif Pelanggan

\begin{tabular}{|c|c|c|c|c|c|c|c|c|}
\hline \multirow{3}{*}{$\begin{array}{l}\text { Kredibilitas } \\
\text { Narasumber }\end{array}$} & \multicolumn{6}{|c|}{ Aspek Konatif } & \multirow{2}{*}{\multicolumn{2}{|c|}{ Jumlah }} \\
\hline & \multicolumn{2}{|c|}{ Tinggi } & \multicolumn{2}{|c|}{ Sedang } & \multicolumn{2}{|c|}{ Rendah } & & \\
\hline & $\mathrm{f}$ & $\%$ & $\mathrm{f}$ & $\%$ & $\mathrm{f}$ & $\%$ & $\mathrm{f}$ & $\%$ \\
\hline Baik & 38 & 63,3 & 3 & 5,0 & 2 & 3,3 & 43 & 71,7 \\
\hline $\begin{array}{c}\text { Kurang } \\
\text { Baik }\end{array}$ & 2 & 3,3 & 1 & 1,7 & 3 & 5,1 & 6 & 10,0 \\
\hline Tidak Baik & 7 & 11,7 & 2 & 3,3 & 2 & 3,3 & 11 & 18,3 \\
\hline Jumlah & 47 & 78,3 & 6 & 10,0 & 7 & 11,7 & 60 & 100,0 \\
\hline
\end{tabular}

Tabel 3. diatas menunjukkan mayoritas responden sebesar $63,3 \%$ dari responden yang memiliki pengetahuan dan pemahaman terhadap isi materi komunikasi perusahaan yang berupa acara Dialog Interaktif PDAM Kota Bandung menyatakan kredibilitas narasumber sudah bagus seperti pengalaman dan posisi sumber menimbulkan kepercayaan audiens serta penguasaan materi dan kedekatan sumber dengan audiens juga sangat menunjang, sehingga mereka mempunyai keinginan untuk mengajak pelanggan lain agar berpartisipasi dalam acara Dialog Interaktif PDAM Kota Bandung relatif tinggi. Hal ini menunjukkan adanya kecenderungan kredibilitas sumber memiliki keterkaitan dengan perilaku pendengar. Sedangkan 11,7\% responden menyatakan bahwa kredibilitas narasumber Dialog Interaktif tidak baik tetapi mereka memiliki perilaku untuk mengajak dan menginformasikan tentang kegiatan PDAM pada pelanggan lainnya. Hal ini terjadi karena responden merasa jarang mengikuti acara Dialog Interaktif PDAM di radio. Namun, mereka masih memiliki rasa tanggungjawab secara sosial untuk mengkritisi pelayanan PDAM selanjutnya agar lebih baik lagi dalam pelayanan PDAM terhadap pelanggannya.

Sementara itu, keputusan bersedia atau tidaknya mengikuti acara Dialog Interaktif dan menyampaikan berita positif tentang PDAM tergantung dari aspek kognitif dan aspek afektif yang dimiliki oleh pendengar. Ketika seseorang telah memiliki pengetahuan terhadap perusahaan tinggi dan penilaian positif maka akan mempengaruhi keputusan audiens. Dan disisi lain, kredibilitas itu masalah persepsi, kredibilitas berubah-ubah bergantung pada pelaku persepsi komunikan, topik yang dibahas dan situasi (Rakhmat, 1996 : 257). Jadi, tabel 1, 2 dan 3 menunjukkan adanya kecenderungan kredibilitas sumber dapat mempengaruhi aspek kognitif, afektif dan konatif.

Tabel 4. menunjukkan daya tarik isi pesan komunikasi perusahaan yang berupa Dialog Interaktif PDAM Kota Bandung memiliki kecenderungan sangat penting dalam mempertahankan citra perusahaan. Sebanyak 48,4\% dari responden yang memiliki pengetahuan terhadap perusahaan, menyatakan daya tarik pesan yang terdiri dari penyampaian materi, sistematis jawaban, pola pemberian solusi, penggunaan terminologi dan penyajian bukti-bukti yang logis sudah baik, sehingga membantu audiens dalam mempertahankan ingatan responden akan layanan perusahaan terhadap pelanggannya.

Tabel 4. Keterkaitan Antara Daya Tarik Isi Pesan dengan Aspek Kognitif Pelanggan

\begin{tabular}{|c|c|c|c|c|c|c|c|c|}
\hline \multirow{3}{*}{$\begin{array}{l}\text { Daya Tarik } \\
\text { Isi Pesan }\end{array}$} & \multicolumn{6}{|c|}{ Aspek Kognitif } & \multirow{2}{*}{\multicolumn{2}{|c|}{ Jumlah }} \\
\hline & \multicolumn{2}{|c|}{ Tinggi } & \multicolumn{2}{|c|}{ Sedang } & \multicolumn{2}{|c|}{ Rendah } & & \\
\hline & $\mathrm{f}$ & $\%$ & $\mathrm{f}$ & $\%$ & $\mathrm{f}$ & $\%$ & $\mathrm{f}$ & $\%$ \\
\hline Baik & 29 & 48,4 & 4 & 6,7 & 2 & 3,3 & 35 & 58,4 \\
\hline $\begin{array}{c}\text { Kurang } \\
\text { Baik }\end{array}$ & 5 & 8,3 & 4 & 6,7 & 2 & 3,3 & 11 & 18,3 \\
\hline Tidak Baik & 5 & 8,3 & 7 & 11,6 & 2 & 3,4 & 14 & 23,3 \\
\hline Jumlah & 39 & 65,0 & 15 & 25,0 & 6 & 10,0 & 60 & 100,0 \\
\hline
\end{tabular}

Sedangkan 3,4\% dari responden yang memiliki pengetahuan rendah terhadap perusahaan, menyatakan siaran Dialog Interaktif PDAM Kota Bandung tidak menarik. Hal ini terjadi karena responden tidak begitu peduli akan isi materi Dialog Interaktif PDAM Kota Bandung disebabkan mereka sudah menilai citra PDAM tidak baik dari segi pelayanan kualitas PDAM terhadap pelanggannya yaitu dengan buktinya jumlah angka meteran yang tidak sesuai dengan jumlah pemakaian air yang digunakan responden. Namun, sebanyak 8,3\% dari responden yang memiliki pengetahuan terhadap perusahaan tinggi, berpendapat Dialog Interaktif PDAM yang disiarkan oleh radio swasta lokal tidak menarik. Hal ini dapat terjadi karena responden menganggap bahwa mereka tahu akan kegiatan PDAM yaitu dari seringnya ia bertanya kepada karyawan PDAM disaat melakukan pembayaran rekening air dan bukan dari isi materi yang disampaikan dalam Dialog Interaktif.

Menurut Sutisna (2002:278) bahwa untuk menampilkan pesan iklan (Dialog Interaktif) yang mampu membujuk, mampu membangkitkan dan mempertahankan ingatan konsumen/pelanggan akan produk/perusahaan yang ditawarkan, memerlukan daya tarik bagi audiens sasaran. Daya tarik iklan (Dialog Interaktif) sangat penting karena akan meningkatkan keberhasilan komunikasi dengan audiens. Sedangkan berdasarkan karakteristik pendengar radio siaran yang harus dipahami dan disikapi dengan benar oleh penyiar agar isi siaran dialog interaktif PDAM Kota Bandung dapat menarik perhatian pendengarnya (pelanggannya), maka si penyiar dan narasumber harus tahu bahwa biasanya pendengar dapat berkomunikasi langsung secara interpersonal dengan menggunakan gaya "ngobrol" sehingga antara penyiar dan narasumber harus dapat membayangkan seolah-olah sedang berbicara kepada satu orang saat siaran (Romli, 2009:21).

Tabel 5. menunjukkan kecenderungan adanya keterkaitan antara daya tarik isi pesan komunikasi perusahaan dalam bentuk Dialog Interaktif PDAM Kota Bandung dengan perasaan dan penilaian 
responden terhadap perusahaan. Keadaan demikian sebenarnya harus sesuai dengan Psikolinguis yaitu upaya mempelajari bagaimana maksud komunikator diubah menjadi pesan dalam lambang yang diterima secara kultural dan bagaimana signal-signal ini diubah menjadi penafsiran komunikan. Sehingga sebetulnya setiap kata (dalam isi pesan) melahirkan konotasi yang berlainan bagi setiap orang, bergantung pada pengalaman hidupnya. Berkaitan dengan daya tarik isi pesan yang mengandung makna konotatif, maka Osgood, Suci dan Tanenbaum(1957) mengembangkan alat untuk mengukur makna konotatif suatu kata (dalam isi pesan) yang disebut dengan semantic differentials. Sehingga kita tahu bahwa kata yang kita ucapkan mungkin diartikan lain oleh komunikate (Rakhmat, 1996:281). Hal ini terlihat pada tabel diatas, sebanyak 38,3\% dari responden yang memiliki penilaian positif terhadap perusahaan, menyatakan daya tarik pesan dalam Dialog interaktif sudah baik karena dalam penyampaian materi, narasumber berusaha agar isi materi tersebut dapat menggugah perasaan emosional pendengar melalui penyajian jawaban yang sistematis, mudah dipahami dan jelas oleh pendengar. Sedangkan $6,7 \%$ dari responden yang memiliki penilaian positif terhadap perusahaan dalam Dialog Interaktif PDAM menyatakan tidak menarik disebabkan responden menyatakan bahwa isi materinya tidak relevan dengan apa yang dilakukan oleh pihak PDAM namun, mereka masih mempunyai daya loyalitas tinggi terhadap eksistensi perusahaan dengan melakukan pembayaran rekening air sesuai jadwal yang telah ditentukan dan menginformasikan pipa distribusi air yang bocor ke pihak PDAM.

Tabel 5. Keterkaitan Antara Daya Tarik Isi Pesan dengan Aspek Afektif Pelanggan

\begin{tabular}{ccccccccc}
\hline & \multicolumn{9}{c}{ Aspek Afektif } & \multirow{2}{*}{ Jumlah } \\
\cline { 2 - 7 } Daya Tarik \\
\cline { 2 - 7 } Isi Pesan & Tinggi & \multicolumn{3}{c}{ Sedang } & \multicolumn{2}{c}{ Rendah } & & \\
\cline { 2 - 8 } & $\mathrm{f}$ & $\%$ & $\mathrm{f}$ & $\%$ & $\mathrm{f}$ & $\%$ & $\mathrm{f}$ & $\%$ \\
\hline Baik & 23 & 48,4 & 5 & 8,4 & 7 & 11,7 & 35 & 58,4 \\
Kurang Baik & 5 & 8,3 & 4 & 6,7 & 2 & 3,3 & 11 & 18,3 \\
Tidak Baik & 4 & 6,7 & 1 & 1,6 & 9 & 15,0 & 14 & 23,3 \\
\hline Jumlah & 32 & 53,3 & 10 & 16,7 & 18 & 30,0 & 60 & 100,0 \\
\hline
\end{tabular}

Selanjutnya $15,0 \%$ dari responden yang memiliki perasaan tidak suka terhadap perusahaan dalam Dialog Interaktif PDAM Kota Bandung menyatakan tidak menarik Hal ini disebabkan oleh adanya penilaian responden yang sudah beberapa kali mengikuti siaran Dialog Interaktif kemudian berpartisipasi namun, hasilnya tetap juga tidak ada perubahan dan ketika menyampaikan keluhannya sehingga responden mampunyai perasaan dan penilaian yang tidak baik terhadap PDAM. Hal yang penting dalam acara siaran dialog interaktif di radio harus bisa menampilkan suasana yang "hangat" dalam artian isi siaran memadukan kata-kata, musik dan efek suara yang mampu mempengaruhi emosi pendengar. Pendengar akan bereaksi atas kehangatan yang diciptakan melalui suara penyiar dan narasumber sehingga seringkali bahwa penyiar dianggap sebagai seorang teman bagi mereka (Romli, 2009:20).

Tabel 6. Keterkaitan Antara Daya Tarik Isi Pesan dengan Aspek Konatif Pelanggan

\begin{tabular}{|c|c|c|c|c|c|c|c|c|}
\hline \multirow{3}{*}{$\begin{array}{l}\text { Daya Tarik } \\
\text { Isi Pesan }\end{array}$} & \multicolumn{6}{|c|}{ Aspek Konatif } & \multirow{2}{*}{\multicolumn{2}{|c|}{ Jumlah }} \\
\hline & \multicolumn{2}{|c|}{ Tinggi } & \multicolumn{2}{|c|}{ Sedang } & \multicolumn{2}{|c|}{ Rendah } & & \\
\hline & $\mathrm{f}$ & $\%$ & $\mathrm{f}$ & $\%$ & $\mathrm{f}$ & $\%$ & $f$ & $\%$ \\
\hline Baik & 33 & 55,0 & 2 & 3,3 & 0 & 0 & 35 & 58,4 \\
\hline $\begin{array}{c}\text { Kurang } \\
\text { Baik }\end{array}$ & 7 & 11,7 & 3 & 5,0 & 1 & 1,6 & 11 & 18,3 \\
\hline Tidak Baik & 7 & 11,6 & 1 & 1,7 & 6 & 10,1 & 14 & 23,3 \\
\hline Jumlah & 47 & 78,3 & 6 & 10,0 & 7 & 11,7 & 60 & 100,0 \\
\hline
\end{tabular}

Tabel 6. menunjukkan mayoritas responden yaitu sebesar 55,0\% dari responden yang memiliki keinginan untuk mengajak dan berpartisipasi dalam komunikasi perusahaan yang berbentuk Dialog Interaktif PDAM Kota Bandung, menyatakan daya tarik pesan dalam Dialog Interaktif sudah bagus, sehingga mereka bersedia untuk mengikuti dan menginformasikan tentang PDAM relatif tinggi. Hal ini menunjukkan adanya kaitan antara daya tarik pesan yang terdiri dari penyampaian materi, sistematis jawaban, pola pemberian solusi, penggunaan terminologi dan penyajian bukti-bukti logis sudah bagus dan memiliki keterkaitan dengan perilaku responden dan didukung oleh pernyataan responden yang mengatakan bahwa PDAM mulai menyadari beberapa kekurangannya dalam melayani pelanggannya sehingga hal ini menjadi nilai tersendiri di benak pendengar yang dapat meningkatkan aspek konasinya.

Keadaan diatas dapat dipahami bahwa dalam melakukan siaran dialog interkatif di radio, maka penyiar dan narasumber yang akan tampil "on air" harus dapat mempersiapkan naskah siaran dengan baik sehingga pendengar akan terkesan dan mempunyai keinginan untuk mengajak orang lain agar mau mengikuti acara siaran dialog interaktif. Hal ini dapat dilakukan apabila isi naskah siaran bersifat jelas, yaitu sekali ucap langsung dapat dimengerti oleh pendengar; ringkas, yaitu satu ide untuk satu kalimat sebagaimana kalimat yang biasa diucapkan saat bercakap-cakap; sederhana, yaitu kata-kata yang disampaikan disaat siaran mudah untuk dipahami secara umum dan tidak terlalu banyak mengandung istilah-istilah teknis; aktif, yaitu menggunakan kalimat aktif; imajinatif; logis dan bergaya story telling (bertutur/bercerita) (Romli, 2009:55-58).

Sedangkan 10,1\% dari responden yang memiliki keinginan rendah untuk mengajak dan berpartisipasi dalam Dialog Interaktif, menyatakan yang disiarkannya itu tidak dapat menarik, sehingga mereka tidak memiliki penilaian khusus terhadap apa yang disampaikan dalam Dialog Interaktif PDAM Kota Bandung dikarenakan mereka sibuk dengan aktivitasnya sehari-hari sehingga tidak tuntas untuk mendengarkan acara Dialog interaktif 
itu sampai selesai. Selanjutnya, sebanyak $11,6 \%$ dari responden yang menyatakan bersedia untuk mengajak dan berpartisipasi dalam Dialog Interaktif PDAM Kota Bandung, menyatakan daya tarik pesannya tidak bagus. Hal ini disebabkan oleh kurangnya loyalitas mereka terhadap perusahaan dan hanya sebatas mendengarkannya saja, sehingga mereka tidak begitu memperhatikan isi materi yang disampaikan oleh narasumber dan yang paling penting yang mereka harapkan adalah adanya peningkatan pelayanan PDAM terhadap pelanggannya dengan tidak membedabedakan status ekonomi pelanggannya. Sebenarnya kesadaran akan kebutuhan sesuatu hal (informasi) yang menunjukkan pada perilaku (aspek konatif) akan nampak ketika kondisi ideal paralel dengan kondisi aktual terjadi ketimpangan yang akan menunjukkan adanya kesadaran pada kesempatan (Sutisna, 2002:20).

Tabel 7. Keterkaitan Antara Intensitas Pesan dengan Aspek Kognitif Pelanggan

\begin{tabular}{ccccccccc}
\hline \multirow{2}{*}{$\begin{array}{c}\text { Intensitas } \\
\text { Pesan }\end{array}$} & \multicolumn{9}{c}{ Tspek Kognitif } & \multirow{2}{*}{ Jumlah } \\
\cline { 2 - 7 } & Tinggi & \multicolumn{2}{c}{ Sedang } & \multicolumn{2}{c}{ Rendah } & & \\
\cline { 2 - 7 } & $\mathrm{f}$ & $\%$ & $\mathrm{f}$ & $\%$ & $\mathrm{f}$ & $\%$ & $\mathrm{f}$ & $\%$ \\
\hline Baik & 28 & 46,6 & 8 & 13,3 & 1 & 1,7 & 37 & 61,6 \\
Kurang Baik & 3 & 5,0 & 4 & 6,7 & 0 & 0 & 7 & 11,7 \\
Tidak Baik & 8 & 13,4 & 3 & 5,0 & 5 & 8,3 & 16 & 26,7 \\
\hline Jumlah & 39 & 65,0 & 15 & 25,0 & 6 & 10,0 & 60 & 100,0 \\
\hline
\end{tabular}

Menurut Tannenbaum yang merumuskan teori kesesuaian/keselarasan (congruity principle) mengatakan bahwa unsur-unsur kognitif mempunyai valensi positif, negatif atau nol dalam berbagai intensitas. Unsur-unsur yang relevan satu sama lain dapat mempunyai hubungan yang positif atau negatif. Kesesuaian akan terjadi apabila semua tanda hubungan adalah nol atau dua diantaranya negatif, dan bila intensitasnya sama (Secord \& Backman, 1964 dalam Azwar, 1988:34).

Tabel 7. menunjukkan bahwa mayoritas responden, sebesar $46,6 \%$ dari responden yang memiliki pengetahuan terhadap perusahaan tinggi, berpendapat bahwa intensitas pesankomunikasi perusahaan dalam bentuk Dialog Interaktif PDAM Kota Bandung di radio adalah bagus dalam arti frekuensi, durasi dan jam siar Dialog Interaktif telah sesuai, dan oleh karenanya mereka pun mengetahui layanan PDAM bagi pelanggannya. Hal ini menunjukkan bahwa intensitas yang sesuai/tepat dalam menyiarkan Dialog Interaktif memiliki kecenderungan yang tinggi dalam sebuah kegiatan customer relations.

Intensitas siaran Dialog Interaktif terdiri dari frekuensi, durasi dan jam siar. Sebanyak 46,6\% menyatakan intensitas siaran Dialog Interaktif PDAM Kota Bandung sudah tepat, baik frekuensi, durasi maupun jam siar. Durasi yang tepat yaitu 1-2 jam, dalam hal ini cukup mempengaruhi pengetahuan publik, karena tidak terlalu membosankan. Kemudian kemunculan Dialog Interaktif yang relatif sering, hampir dwi-tri bulanan berpengaruh pada pengetahuan audiens. Hasil penelitian menunjukkan adanya kecenderungan semakin sering audiens diterpa Dialog Interaktif maka akan semakin tinggi pula tingkat pengetahuannya terhadap layanan perusahaan. Demikian juga dengan jam siar yang tepat/sesuai acara dimana target audiens Dialog Interaktif ini adalah para pelanggan yang banyak meluangkan waktunya secara leluasa yaitu rata-rata kaum wiraswasta, pensiunan dan ibu rumah tangga.

Sedangkan $13,4 \%$ dari responden yang memiliki pengetahuan terhadap perusahaan tinggi, menyatakan intensitas pesan siaran Dialog Interaktif PDAM Kota Bandung tidak baik dikarenakan responden tidak banyak memiliki waktu senggang ketika Dialog Interaktif disiarkan di radio Maraghita namun, mereka mempunyai pengetahuan tentang kegiatan layanan PDAM tidak hanya didapat dari Dialog Interktif tetapi dari hasil bertanya kepada pelanggan lainnya dan membaca informasi seputar layanan PDAM di media cetak. Selanjutnya, sebesar $8,3 \%$ dari responden yang memiliki pengetahuan terhadap perusahaan rendah, menyatakan intensitas pesan dalam Dialog Interaktif PDAM Kota Bandung tidak baik atau belum tepat sehingga pengetahuan mereka tentang perusahaan relatif rendah, seperti yang telah dibahas diatas bahwa banyak faktor yang dapat membentuk sikap audiens khususnya aspek kognitif selain intensitas pesan, sehingga hal diatas dapat terjadi. Dan sebanyak 6,7\% dari responden yang memiliki pengetahuan terhadap perusahaan sedang, menyatakan intensitas siaran Dialog Interaktif PDAM kurang atau kurang tepat, sehingga mereka pun kurang mengetahui layanan PDAM bagi pelanggannya.

Tabel 8. Keterkaitan Antara Intensitas Pesan dengan Aspek Afektif Pelanggan

\begin{tabular}{ccccccccc}
\hline \multirow{2}{*}{$\begin{array}{c}\text { Intensitas } \\
\text { Pesan }\end{array}$} & \multicolumn{9}{c}{ Aspek Afektif } & \multicolumn{2}{c}{ Jumlah } \\
\cline { 2 - 7 } & \multicolumn{2}{c}{ Tinggi } & \multicolumn{3}{c}{ Sedang } & \multicolumn{2}{c}{ Rendah } & \multicolumn{2}{c}{} \\
\cline { 2 - 7 } & $\mathrm{f}$ & $\%$ & $\mathrm{f}$ & $\%$ & $\mathrm{f}$ & $\%$ & $\mathrm{f}$ & $\%$ \\
\hline Baik & 27 & 45,0 & 4 & 6,6 & 6 & 10,0 & 37 & 61,6 \\
$\begin{array}{c}\text { Kurang } \\
\text { Baik }\end{array}$ & 4 & 6,7 & 0 & 0 & 3 & 5,0 & 7 & 11,7 \\
$\begin{array}{c}\text { Tidak } \\
\text { Baik }\end{array}$ & 1 & 1,6 & 6 & 10,1 & 9 & 15,0 & 16 & 26,7 \\
\hline Jumlah & 32 & 53,3 & 10 & 16,7 & 18 & 30,0 & 60 & 100,0 \\
\hline
\end{tabular}

Tabel 8. menunjukkan adanya kecenderungan intensitas komunikasi perusahaan dalam bentuk siaran Dialog Interaktif PDAM Kota Bandung memiliki keterkaitan dengan penilaian responden terhadap perusahaan. Sebanyak $45,0 \%$ dari responden yang memiliki perasaan dan penilaian positif terhadap perusahaan dalam Dialog Interaktif sudah bagus. Hal ini berkaitan dengan tabel 7 bahwa frekuensi, durasi dan jam siar Dialog Interaktif PDAM Kota Bandung telah tepat sehingga memiliki kecenderungan berpengaruh terhadap 
aspek afektif audiens. Artinya hal ini sesuai dengan teori general semantic tentang dating (penanggalan) yang menyatakan "Dating memaksa individu untuk mengakui faktor perubahan, untuk menilai lingkungan, untuk membuat ujaran verbal yang cocok dengan fakta kehidupan yang ada dewasa ini" (William Arnold dan James McCroskey dalam Rakhmat, 1996:285).

Hasil penelitian menunjukkan dengan seringnya mereka menyimak atau mengikuti acara Dialog Interaktif yang mencoba mengkomunikasikan bentuk dan pola pelayanan perusahaan untuk menjalin hubungan baik dengan pelanggannya dalam usaha meningkatkan citra positif di mata publiknya dapat menimbulkan rasa simpati dan suka pendengar terhadap perusahaan. Terbukti mayoritas responden yang memiliki penilaian positif terhadap perusahaan, menyatakan intensitas Dialog Interaktif PDAM Kota Bandung sudah bagus, dan hanya $15,0 \%$ dari responden yang memiliki perasaan dan penilaian negatif terhadap perusahaan dalam Dialog Interaktif PDAM Kota Bandung, menyatakan belum tepat. Hal ini dikarenakan oleh tidak tahunya responden akan tepatnya jadwal Dialog Interaktif PDAM Kota Bandung selanjutnya di radio dan yang mereka ketahui hanya sebatas jadwal bulanannya. Dan disisi lain, dengan intensitas pesan Dialog Interaktif yang relatif sering dilaksanakan dapat menimbulkan suatu efek perasaan yang berbeda tiap waktunya bagi seseorang karena kepribadian (sikap) seseorang dapat dipengaruhi oleh suasana faktor lingkungan tertentu (bisa positif atau negatif) ketika mengikuti acara tersebut. Maka, intensitas isi pesan program Dialog Interaktif PDAM Kota Bandung sesuai dengan teori keseimbangan yang dikemukakan oleh Heider (Mann, 1969; Secord \& Backman, 1964) dalam Azwar(1988:33) bahwa inti teori ini adalah bahwa individu akan mengatakan suatu afek positif atau afek negatif terhadap orang lain cenderung akan berada dalam keadaan seimbang dengan afek afek seseorang terhadap suatu objek sikap dimana orang lain itu juga mengarahkan sikapnya tersebut.

Lebih lanjut, menurut Heider (1958) dalam Rakhmat (1996), apabila kita mengamati perilaku sosial, pertama-tama kita menentukan dahulu apa yang menyebabkannya apakah faktor situasional atau personal yang dalam teori atribusi lazim disebut kausalitas eksternal dan kausalitas internal. Atribusi itu sendiri menurut Baron dan Bryrne (1979:56) dalam Rakhmat (1996:93) adalah proses menyimpulkan motif, maksud dan karakteristik orang lain dengan melihat pada perilakunya yang tampak.

Pengukuran sikap (aspek konatif) seharusnya dapat diandalkan (reliabel) dan sahih (valid) maka pengukuran sikap dan hubungannya dengan perilaku harus melibatkan parameter waktu. Rentang waktu yang lebih lama antara pengukuran sikap dan waktu untuk berperilaku (enam bulan misalnya) akan mempunyai hubungan yang kurang kuat. (Sutisna, 2002:116).
Tabel 9. Keterkaitan Antara Intensitas Pesan dengan Aspek Konatif Pelanggan

\begin{tabular}{|c|c|c|c|c|c|c|c|c|}
\hline \multicolumn{9}{|c|}{ Aspek Konatif } \\
\hline \multirow[t]{2}{*}{$\begin{array}{c}\text { Intensitas } \\
\text { Pesan }\end{array}$} & \multicolumn{2}{|c|}{ Tinggi } & \multicolumn{2}{|c|}{ Sedang } & \multicolumn{2}{|c|}{ Rendah } & \multicolumn{2}{|c|}{ Jumlah } \\
\hline & $\mathrm{f}$ & $\%$ & $\mathrm{f}$ & $\%$ & f & $\%$ & $\mathrm{f}$ & $\%$ \\
\hline Baik & 28 & 46,6 & 3 & 5,0 & 6 & 10,0 & 37 & 61,6 \\
\hline $\begin{array}{c}\text { Kurang } \\
\text { Baik }\end{array}$ & 6 & 10 & 1 & 1,7 & 0 & 0 & 7 & 11,7 \\
\hline Tidak Baik & 13 & 21,7 & 2 & 3,3 & 1 & 1,7 & 16 & 26,7 \\
\hline Jumlah & 47 & 78,3 & 6 & 10,0 & 7 & 11,7 & 60 & 100,0 \\
\hline
\end{tabular}

Tabel 9 menunjukkan mayoritas responden yaitu sebesar 46,6\% dari responden yang memiliki aspek konatif yang tinggi, menyatakan intensitas pesan komunikasi perusahaan dalam bentuk siaran Dialog Interaktif PDAM Kota Bandung sudah bagus, sehingga kecenderungan mereka untuk mengajak pelanggan lain dan mengikuti secara aktif acara Dialog Interaktif PDAM relatif tinggi. Hal ini menunjukkan adanya kecenderungan intensitas pesan Dialog Interaktif berpengaruh pada kecenderungan berperilaku dengan buktinya bahwa banyak responden yang telah mengikuti Dialog Interaktif lebih dari 6 kali berusaha untuk mengajak pelanggan lain agar berpartisipasi dalam Dialog Interaktif PDAM di radio-radio swasta lainnya. Dan hanya $21,7 \%$ responden yang memiliki aspek konatif tinggi, menyatakan intensitas pesan dalam Dialog Interaktif PDAM Kota Bandung di radio Maraghita belum tepat dikarenakan responden hanya menyampaikan saran, keluhan dan kritiknya saja melalui acara Dialog Interaktif PDAM karena tidak banyak memiliki waktu yang banyak untuk mendengarkan acara tersebut sampai akhir.

Walaupun demikian, masih ada responden sebanyak $10,0 \%$ yang menyatakan intensitas pesan Dialog Interaktif PDAM Kota Bandung sudah baik namun, mereka memiliki aspek konatif yang rendah dikarenakan mereka hanya mengikuti saja acara Dialog interaktif PDAM di radio tanpa mempunyai keberanian untuk bertanya, mengajak bahkan menginformasikan berita positif tentang PDAM, karena mereka beranggapan bahwa masalahnya sudah terwakili oleh beberapa pendengar lainnya/ pelanggan yang berpartisipasi dalam acara tersebut.

Tabel 10. Keterkaitan Antara Terpaan Dialog Interaktif PDAM Kota Bandung dengan Sikap Positif Pelanggan Pada Perusahaan

\begin{tabular}{ccccccccc}
\hline \multirow{2}{*}{$\begin{array}{c}\text { Terpaan } \\
\text { Dialog } \\
\text { Interaktif }\end{array}$} & \multicolumn{9}{c}{ Tingap Positif Pelanggan } & \multicolumn{2}{c}{ Sedang } & \multicolumn{2}{c}{ Rendah } & \multirow{2}{*}{ Jumlah } \\
\cline { 2 - 7 } & f & $\%$ & $\mathrm{f}$ & $\%$ & $\mathrm{f}$ & $\%$ & $\mathrm{f}$ & $\%$ \\
\hline Baik & 32 & 53,3 & 3 & 5,0 & 1 & 1,7 & 36 & 60,0 \\
Kurang & 10 & 16,7 & 3 & 5,0 & 3 & 5,0 & 16 & 6,7 \\
Baik & & & & & & & & \\
Tidak Baik & 3 & 5 & 0 & 0 & 5 & 8,3 & 8 & 13,3 \\
\hline Jumlah & 45 & 75,0 & 6 & 10,0 & 9 & 15,0 & 60 & 100,0 \\
\hline
\end{tabular}


Dari hasil perhitungan tabulasi silang komponen variabel utama terpaan Dialog Interaktif PDAM Kota Bandung dengan sikap positif pelanggan pada perusahaannya dapat menunjukkan bahwa 53,3\% responden menyatakan dengan adanya kegiatan Dialog Interaktif PDAM di radio-radio swasta lokal di Bandung maka pelanggan merasa dipermudah oleh pihak perusahaan untuk menyampaikan bermacam-macam keluhan, saran dan kritiknya bagi perusahaan sehingga hubungan yang baik antara PDAM Kota Bandung dengan pelanggannya dapat berjalan dengan baik. Namun, masih ada responden sebanyak 16,7\% yang menyatakan terpaan Dialog Interaktif PDAM Kota Bandung kurang baik tetapi memiliki sikap positif tinggi pada perusahaan. Hal ini dikarenakan responden masih sangat tergantung pada PDAM Kota Bandung khususnya dalam penyediaan sarana air bersih bagi masyarakat perkotaan, yang akibatnya mereka masih mempunyai sikap positif terhadap PDAM walaupun ada beberapa hal yang perlu diperbaiki oleh pihak manjemen PDAM Kota Bandung dalam hal pelayanan perusahaan terhadap pelanggannya yang disampaikan dalam acara Dialog Interaktif.

Selanjutnya, hanya $8,3 \%$ responden yang menyatakan terpaan Dialog Interaktif PDAM Kota Bandung tidak baik dengan mempunyai sikap positif yang rendah terhadap perusahaan. Hal ini terbukti dengan adanya beberapa pendengar yang mengatakan acara Dialog Interaktif PDAM Kota Bandung kurang efektif dalam meningkatkan sikap positif pelanggannya tetapi yang harus dilakukan adalah adanya peningkatan pelayanan oleh pihak manajemen PDAM terhadap pelanggan yang selaras dengan apa yang pernah dikemukakan narasumber dalam Dialog Interaktif sebagai wujud rasa tanggung jawab sosial dan komitmen perusahaan milik pemerintah dalam melayani publiknya.

Komunikasi perusahaan adalah syarat yang digunakan untuk menggambarkan komunikasi yang dilakukan antara perusahaan dan publik eksternal. Program komunikasi perusahaan biasanya terintegrasikan dengan kegiatan kehumasan yang mencangkup kegiatan internal seperti employee gathering, reward and punishmen, pembuatan house journal, corporate identity (seragam pekerjaan). Sedangkan kegiatan eksternalnya meliputi iklan perusahaan, press release, wawancara pers, tour company, dialog interaktif, dan lain sebagainya. Secara definisi, komunikasi perusahaan adalah kegiatan komunikasiyang dilakukan oleh organisasi sebagai sebuah entitas perusahaan dan di dalamnya termasuk pengelolaan kegiatan kehumasan, situs perusahaan, laporan tahunan, program pengenalan perusahaan, logo perusahaan, dan setiap bentuk iklan korporasi yang dikerjakan oleh perusahaan itu. Lebih lanjut, Van Riel (2005) dalam Butterick (2012:180) menyatakan bahwa komunikasi perusahaan adalah suatu alat manajemen yang secara seefektif dan seefisien berupaya mengharmonisasikan berbagai bentuk jalinan komunikasi internal dan eksternal yang dilakukan secara sengaja, sehingga tercipta suasana yang saling menguntungkan bagi kedua belah pihak atau kelompok yang berkepentingan secara organisatoris dan aspek sosial.

Dengan demikian, sebenarnya dalam proses terjalinnya komunikasi perusahaan terdapat fungsi promosi, pemasaran dan penjualan bagi sebuah produk dan jasa suatu perusahaan agar diketahui oleh publik. Sehingga dengan adanya komunikasi perusahaan yang terjalin antara perusahaan dengan publiknya (pelanggan/ calon pelanggan) akan membuat kesan positif mengenai perusahaan dengan berbagai aktifitas-aktifitas publik yang dilakukannya, mulai dari seberapa cepat dan bagaimana cara pelayanan perusahaan dapat memberikan kepuasan bagi pelanggannya.

Program talkshow atau chat show (obrolan, bincang-bincang, dialog interaktif) biasanya mendatangkan narasumber atau bintang tamu untuk berbincangbincang tentang sebuah tema atau topik hangat yang sedang berkembang. Program dialog interaktif yang diselenggarakan melalui radio siaran dianggap dapat menguntungkan karena sifat radio siaran yang terkategorikan berbiaya murah, jaringan cukup luas, dan memiliki kekuatan langsung yang tidak mengenal jarak, rintangan dan memiliki daya tarik tersendiri dalam hal suara, musik dan efek suara. Dan yang paling penting dari siaran di radio yaitu lembaga yang dipandang sebagai "kekuatan kelima" (the fifth estate) setelah eksekutif (lembaga pemerintah), legislatif (lembaga parlemen), yudikatif (lembaga peradilan), dan pers atau surat kabar (Romli, 2009:17).

Berkaitan dengan kegiatan dialog interaktif sebagai bentuk komunikasi perusahaan PDAM Kota Bandung terhadap pelanggannya, maka menurut Herbert C.Kelman(1975)dalamRakhmat(1996:256)menyatakan bahwa pengaruh komunikasi kita (perusahaan) pada orang lain (stakeholdersnya) berupa tiga hal yaitu internalisasi yang terjadi bila orang menerima pengaruh karena perilaku yang dianjurkan itu sesuai dengan sistem nilai yang dimilikinya, identifikasi yang terjadi bila individu mengambil perilaku yang berasal dari orang atau kelompok lain karena perilaku itu berkaitan dengan hubungan yang mendefinisikan diri secara memuaskan dengan orang atau kelompok itu dan ketundukan yang terjadi bila individu menerima pengaruh dari orang atau kelompok lain karena ia berharap memperoleh reaksi yang menyenangkan dari orang atau kelompok tersebut. Dan hal ini terbukti dengan media massa mampu membentuk bahkan meningkatkan sikap dan citra positif orang tentang lingkungan/perusahaan/organisasi dengan menyampaikan informasi, pengetahuan, keterampilan dan nilai-nilai baik yang dilaksanakan secara teratur oleh komunikator/narasumber perusahaan untuk menerpa sasaran khalayaknya.

Dalam perspektif siaran di radio, maka ada beberapa variasi program siaran seperti mengundang 
pendengar mengudara via telepon (phone-in) untuk menyampaikan opininya dengan topik khusus, atau program yang bersifat "terbuka" (open-line phone-in), yaitu pendengar bebas berbicara tentang apa saja, juga acara diskusi, yaitu penyiar bertindak sebagai moderator (Romli, 2009:79). Adapun penyiar dan narasumber dalam program dialog interaktif PDAM Kota Bandung harus memenuhi kriteria diantaranya adalah harus berwawasan luas, kritis, analitis, memahami tema apa yang disampaikan dalam acara tersebut.

Selanjutnya, menurut Asch (1952) dalam Rakhmat, semua sikap bersumber pada organisasi kognitif dalam artian informasi dan pengetahuan yang kita miliki. Sehingga secara singkat sikap ditentukan oleh citra, yang pada gilirannya citra ditentukan oleh sumbersumber informasi. Diantara sumber informasi yang paling penting dalam kehidupan modern ialah media massa. Jadi, media massa tidak mengubah sikap secara langung tetapi, mengubah dahulu citra dan citra mendasari sikap (Rakhmat, 1996:233). Apabila dihubungkan dengan kegiatan dialog interaktif PDAM Kota Bandung yang dilakukan di radio-radio swasta lokal telah menunjukkan upaya untuk merubah citra perusahaan yang terkesan tertutup akan informasi menjadi perusahaan yang tanggap/ terbuka akan informasi yang berasal dari publiknya sehingga diharapkan dapat mendasari perubahan sikap pelanggan menjadi positif terhadap perusahaan yang diikuti dengan adanya peningkatan kualitas layanan secara signifikan.

Guna lebih lanjut mengetahui bagaimana sikap bisa memprediksi perilaku, hal ini dapat dijelaskan dengan teori Reasoned Action dari Fishbein yang dikutip oleh Assael (1992) dalam Sutisna, bahwa terdapat situasi ketika seseorang mempunyai sikap positif terhadap suatu objek, tetapi sikap tersebut tidak disertai dengan perilaku. Perbedaan sikap dengan perilaku disebabkan oleh banyak alasan yang didukung oleh kepercayaan sebagai akibat yang dirasakan dari tindakan daripada sebagai atribut-atribut merek yang dirasakan (Sutisna, 2002:113114). Dengan demikian, kegiatan dialog interaktif yang dilakukan oleh PDAM Kota Bandung di radio-radio swasta lokal selama ini dapat meningkatkan sikap positif pelanggannya terhadap perusahaan yang terbukti sebagian besar pelanggan telah pro aktif menyampaikan berbagai macam informasi seputar layanan manajemen PDAM Kota Bandung melalui media/saluran komunikasi lainnya seperti media jejaring sosial dan hotline telephone pengaduan pelanggan. Apabila dipandang secara praktis, maka hal ini menunjukkan bahwa telah terjadi pergeseran pemahaman pelanggan yang tadinya kurang simpati berubah menjadi merasa memiliki akan keberadaan PDAM Kota Bandung sebagai perusahaan aset milik pemerintah kota yang perlu dijaga dan tetap diawasi sebagai wujud pelaksanaan check and balance dari keterbukaan informasi publik diantara perusahaan dengan pelanggannya.
Impelementasi komunikasi perusahaan berupa dialog interaktif di radio siaran yang dilakukan secara berkelanjutan oleh PDAM Kota Bandung terhadap pelanggannya menghasilkan penguatan secara kognitif, afektif dan konatif pelanggan mengenai perusahaan. Dari unsur sikap pelanggan PDAM Kota Bandung tersebut diharapkan akan memberikan pencitraan positif terhadap perusahaan di mata khalayaknya sebagai perusahaan yang bonafit, handal dan profesional dalam pengelolaan sumber daya air dan pengendalian lingkungan. Perubahan sikap dapat terjadi jika rangsangan yang diberikan melebihi rangsangan yang diterima oleh organisme sebelumnya dan rangsangan yang dapat merubah sikap adalah rangsangan yang dapat memberikan harapan bagi organisme (Mar'at, 1994:34-36). Maka perubahan respon pelanggan/ konsumen PDAM Kota Bandung dapat dilakukan melalui pemberian rangsangan (terpaan acara dialog interaktif di radio siaran) yang melebihi rangsangan yang diterima sebelumnya dan menghasilkan suatu harapan serta kebutuhan di dalam diri pelanggan/konsumen yang ditimbulkan oleh lingkungan sebagai faktor sosial yang mempengaruhinya. Dari perubahan sikap seseorang tersebut maka selanjutnya akan memberikan kesan, yang berarti gambaran yang diperoleh seseorang tentang suatu fakta sesuai dengan tingkat pengetahuan dan pengertian mereka (terhadap suatu produk, orang, atau situasi) yang biasa disebut dengan citra.

Soemirat dan Ardianto (2004) menjelaskan efek kognitif dari komunikasi sangat mempengaruhi proses pembentukan citra seseorang/lembaga. Citra terbentuk berdasarkan pengetahuan dan informasi-informasi yang diterima seseorang. Komunikasi tidak secara langsung menimbulkan perilaku tertentu, tetapi cenderung mempengaruhi cara kita mengorganisasikan citra kita tentang lingkungan. Kegiatan Komunikasi/Public Relations digambarkan sebagai input-output, proses intern dalam model ini adalah pembentukan citra, sedangkan input adalah stimulus yang diberikan dan output adalah tanggapan atau perilaku tertentu. Sehingga diperlukan suatu manajemen citra yang lebih menekankan dalam upaya mengoptimalkan komunikasi perusahaan yang informatif dan edukatif secara berkesinambungan kepada publik, dengan cara menumbuhkn pengertian yang benar dan simpati sehingga berbagai keunggulan dapat diraih oleh perusahaan, khususnya oleh PDAM Kota Bandung sebagai perusahaan penyedia hajat hidup orang banyak di bidang sumber daya air yang menerapkan Good Corporate Governance (GCG) secara baik dan benar.

\section{SIMPULAN}

Kegiatan komunikasi perusahaan berupa Dialog Interaktif yang dilakukan oleh PDAM Kota Bandung telah dapat meningkatkan dan memperkuat sikap positif pelanggan dari aspek kognitif, afektif maupun konatif mengenai layanan perusahaan terhadap pelanggannya yang meng- 
untungkan bagi citra perusahaan. Selain itu, Dialog Interaktif PDAM Kota Bandung yang disiarkan melalui radio swasta lokal telah memiliki daya tarik yang kuat terhadap perhatian pelanggannya dengan sifat informasi yang disampaikan selalu diiringi dengan musik (berupa jingle budaya perusahan), kata-kata (kuis berhadiah) dan efek suara yang bersifat mengibur, mendidik dan mempersuasi bagi para pendengarnya. Adapun sebagai bentuk implementasi hasil Dialog Interaktif yang disiarkan melalui radio siaran, kini PDAM Kota Bandung melaksanakan pelayanan yang bersifat "extraordinary" bagi pelanggannya dalam hal kuantitas, kualitas dan kontinuitas seputar layanan air bersih, air kotor, maupun layanan laboratorium pengendalian air dan lingkungan yang sesuai dengan good corporate governance (GCG).

Dalam rangka meningkatkan citra perusahaan di mata pelanggannya, sebaiknya PDAM Kota Bandung tidak terbatas pada program dialog interaktif di radio siaran tetapi juga melaksanakan berbagai komunikasi perusahaan dengan publik internal dan eksternal melalui pemanfaatan media publikasi luar ruangan (seperti baligo, spanduk, dan videotron) dan media jejaring sosial lainnya (seperti facebook, instagram, path, dan twitter) yang mendukung terhadap sosialisasi seputar layanan pelanggan dan kebijakan perusahaan.

\section{DAFTAR PUSTAKA}

Azwar, Saifudin.(1988).Sikap Manusia Teori dan Pengukurannya.Jogjakarta: Liberty.

Butterick, Keith.(2012).Pengantar Public Relations: Teori dan Praktik. (Diterjemahkan oleh Nurul Hasfi).Jakarta: Rajawai Press.
Company Profile PDAM Kota Bandung File Arsip Seksi Humas \& Protokol PDAM Kota Bandung

Kotler, Philip. (1995).Manajemen Pemasaran. Alih bahasa Ancella Anitawati Hermawan. Jakarta: Salemba Empat, Pretic e Hall.

Mar'at. (1994). Psikologi Sikap. Jakarta: Gahlia Indonesia.

Moore, H. Frazier.(2004).Hubungan Masyarakat (Satu). Penyunting: Onong Uchjana Effendy. Bandung : Remaja Rosdakarya.

Mulyana, Deddy.(2000).Ilmu Komunikasi Suatu Pengantar.Bandung: PT. Remaja Rosda Karya.

Rakhmat, Jalauddin.(1996). Psikologi Komunikasi Bandung: PT. Remaja Rosda Karya.

(2002).Metode Penelitian Komunikasi. Bandung: PT. Remaja Rosda Karya.

Romli, Asep Syamsul M.(2009).Dasar-dasar Siaran Radio.Bandung: Nuansa Cendekia.

Singarimbun, Masri, dan Effendi, Sofyan.(1995). Metode Penelitian Survai. Edisi Revisi, Jakarta: LP3ES.

Soemirat, Soleh dan Elvinaro Ardianto.(2002).Dasar - Dasar Public Relations. Bandung: Remaja Rosda Karya.

Sutisna.(2002).Perilaku Konsumen \& Komunikasi Pemasaran. Bandung: RemajaRosdakarya. 